\title{
Sobre a Alteração da Moeda - Parte $1^{*}$
}

\author{
Juan de Mariana*
}

\begin{abstract}
Resumo: $\mathrm{O}$ autor argumenta que a prática de desvalorizar a moeda mediante alteração em seu teor metálico é um grande erro. Adverte que quase nunca se desvaloriza a moeda sem múltiplos desastres, atados a prejuízos ainda maiores, no futuro. Critica ainda os reis que impõem tributos ao povo sem prévio consentimento e discorre sobre a duplicidade do valor do dinheiro.
\end{abstract}

Palavras-chave: Moeda, Desvalorização, Tributos, Duplicidade do dinheiro.

\section{On the Alteration of Money - Part 1}

\begin{abstract}
The author argues that the practice of devaluing the currency by change in its metal content was a big mistake. He warns that almost never depreciates the currency without multiple disasters, tied to even greater losses in the future. He also criticizes the kings who levy taxes on people without their consent. The author discusses the duplicity of the value of money.
\end{abstract}

Keywords: Money, Depreciation, Taxes, Duplicity of Money.

Classificação JEL: B11

* O presente artigo é a primeira metade do tratado De Monetae Mutatione, composta pelos capítulos I a VIII da obra. Nossa tradução parte da única edição latina desta obra (Iohannis Marianae e Societate Iesu Tractatus VII. Coloniae: Sumptibus Antonii Hierati, 1609. p. 189-221), também publicada com ajustes mínimos com apêndice do seguinte livro: LAURES, S.J., John. The Political Economy of Juan de Mariana. New York: Fordham University Press, 1928. p. 241-303. O leitor de outrora que procurasse o original latino teria dificuldades para dele encontrar um tomo intacto, visto que o trabalho, escrito e publicado em 1609 contra as políticas monetárias do rei Filipe III (1578-1621) da Espanha, teve quase todos os seus exemplares imediatamente comprados e expurgados pelo monarca, o qual por este texto acusara o autor de lesa-majestade. Sobre esta polêmica em torno da obra, ver: LAURES. Op. cit. p. 5-7. Devido à extensão do De Monetae Mutatione, foi necessário dividir sua publicação em duas partes. A segunda metade do tratado, composta pelos capítulos IX a XIII, será publicada na próxima edição (Volume II, Número 2) de MISES: Revista Interdisciplinar de Filosofia, Direito e Economia.

Traduzido do original em latim para o português, com acréscimo de notas, por Luiz Astorga.

** Juan de Mariana nasceu no ano de 1536 na cidade de Talavera de la Reina, na província de Toledo, no Reino da Espanha, sendo batizado em 2 de abril do mesmo ano. Estudou Artes e Teologia na Universidad de Alcalá de Henares, tendo como mestre do noviciato São Francisco de Borja (1510-1572). Professou os votos na Companhia de Jesus em 1554 em Valladolid, e completou os estudos para a formação sacerdotal no colégio jesuíta de Roma, onde a partir de 1561 se tornou professor de Teologia, e professor do futuro cardeal São Roberto Belarmino (1542-1621). Lecionou, também, em Palermo na Sicília, em Paris na França, e, a partir de 1574, como catedrático de Teologia em Toledo, redigiu a maioria de suas obras. No âmbito da Filosofia Política, o historiador e teólogo espanhol foi um dos grandes representantes da escolástica barroca. Embora amplamente conhecido na literatura ibérica por sua Historia de rebus Hispaniae (História Geral da Espanha) que, escrita em 1592 e traduzida ao vernáculo em 1601, se tornou um dos clássicos da língua de seu país, o jesuíta consolidou para sempre sua notoriedade com o $D e$ Rege et Regis Institutione (Sobre o rei e a instituição real) de 1599, sobre a licitude do tiranicídio. Por circunstâncias históricas várias, a polêmica sobre aquela obra ofuscou contribuições valiosas de sua lavra, como esta que agora apresentamos pela primeira vez em língua portuguesa. O tratado de economia De Monetae Mutatione aborda um tema especialmente atual: se é justa a desvalorização da moeda por parte do governante como meio de enriquecer o erário público. Faleceu em Toledo no dia 16 de fevereiro de 1624. 


\section{Argumento}

No tempo em que havia grande escassez de moeda na Espanha, quase esgotaram o erário as guerras demoradas e espalhadas por vários locais, além de muitas outras dificuldades. Para suprir tal escassez, cogitaram-se e tentaram-se várias soluções. Entre outras, vislumbrou-se desvalorizar a moeda, e isto de duas maneiras. Primeiro, duplicando-se o valor da antiga moeda, de modo que fosse acrescentada para o rei a diferença - isto é, a metade da soma total, o que era um enorme valor. Nisto haveria grande lucro. Segundo, cunhou-se uma nova moeda de cobre ${ }^{1}$ puro, sem qualquer acréscimo de prata (como antes se fazia), dela se retirando metade de seu peso. Assim chegaria ao rei um lucro de mais de dois terços.

Mas são improvidentes as mentes dos homens. Seduzidos pela presente abundância, não consideraram em que males se precipitavam ao seguir tal plano. Porém não faltaram os que criticaram estas ações em seus círculos ou mesmo por escrito, talvez mais cautelosos por ter na memória o passado e os males que nele se deram. $\mathrm{O}$ transcurso dos eventos logo mostrou que não se tratava de profetas ineptos. Os males não pararam por aí. Procurou-se um modo cômodo de destruir ou abolir esta moeda; sobre o tema, vieram muitos a aconselhar que se subtraísse parte do valor da moeda de prata, para deste lucro compensar-se o dispêndio que, previam eles, necessariamente haveria de ocorrer por causa do antigo dinheiro de cobre. O remédio foi muito pior do que a doença, e até hoje foi rejeitado. Ao contrário, determinou-se por um novo decreto que grande parte da nova moeda de cobre fosse recolhida, e a compensação aos seus donos fosse feita a partir do tesouro régio. Tal é a ocasião em que, com renovado esforço, divulgamos esta disputa, por nós iniciada anteriormente; para que a posteridade, repre-

\footnotetext{
${ }^{1}$ A palavra latina aes, normalmente traduzida como "bronze", pode significar também latão ou cobre, como no presente tratado.
}

endida por nossos males, esteja ciente de que quase nunca se desvaloriza a moeda sem ruína para a república²; que o presente lucro implica múltiplos desastres, atados a prejuízos ainda maiores.

\section{Prefácio}

Queira o Deus imortal, e todos os seus santos, que de nossos esforços algo se alcance para o bem público, tal como pedimos com todas as nossas orações; nenhuma outra recompensa eu desejaria e teria como cara, exceto que nosso rei, os que o aconselham, os demais ministros régios, e todos aqueles ante os quais se encontra a administração das coisas, lessem atentamente este folheto, no qual, embora sem refinamentos, nos esforçamos para ilustrar de modo acertado alguns vícios e inconvenientes que, julgo, devem ser evitados com todas as forças.

Havia justificada preocupação acerca das moedas de cobre, hoje cunhadas no país com qualidade inferior à das antigas. Comecei então a empenhar-me neste trabalho, que, embora módico, não se deveria desconsiderar. Não me importa o que de mim hão de dizer os homens - dos quais alguns certamente me acusarão de audácia, outros de excesso de confiança e temeridade - quando, desconsiderando o perigo, eu não hesite em reprovar e repudiar o que homens de maior prudência e experiência consideraram remédio para nossos males.

Desta acusação e culpa me eximirá em parte a sincera vontade de ajudar, e também o fato de que nada nesta disputa se encontrará fora de nosso entendimento. Especialmente quando todo o povo, velhos e jovens, ricos e pobres, doutos e indoutos, clama e lamenta sob este fardo, não pode parecer impressionante que, dentre tantos, alguém ouse pôr em escrito o que, com considerável comoção, se tem criticado abertamente e em reuniões privadas, nas ruas e praças. Ainda que minha serventia se limite a isto, cumprirei correta-

\footnotetext{
${ }^{2} \mathrm{O}$ autor refere-se naturalmente à "coisa pública", ou seja, à pólis ou à sociedade como um todo.
} 
mente o meu dever, pois servir à república é justo aos homens de muita leitura, os quais, por ela, não desconhecem as coisas que ocorreram na história do mundo.

A ilustre cidade de Corinto, como nos conta Luciano de Samósata $(125-180)^{3}$, soube por relatos e rumores que Filipe II (382-336 a.C.) da Macedônia avançava armado contra ela. Em súbito temor e ação, alguns dos cidadãos prepararam armas, outros reforçaram as muralhas, outros produziram suprimentos e instrumentos bélicos. Naquela cidade vivia Diógenes (412-323 a.C.), o Cínico; quando viu que, por ser tido por todos como um inútil, não era chamado a nenhum dos trabalhos e preparações, saiu da barrica em que morava, tomou-a e começou a rolá-la para cima e para baixo com grande vigor. Os cidadãos, indignados com que parecesse rir da calamidade de todos, perguntaram-lhe por que o fazia. Disse ele: "Não é justo que, estando todos ocupados, apenas eu permaneça ocioso".

Quando do levante popular em Atenas - conta-nos Plutarco (45-120) -, como todas as partes ardessem em rebelião, também Sólon (638-558 a.C.), que por sua idade era incapaz de prestar auxílio à pátria, pôs-se armado fora de casa, para mostrar que, na debilidade de suas forças, não lhe faltava a vontade de ajudar. Pois, como diz o profeta Ezequiel (622-570 a.C.), cumpre seu dever o corneteiro, se sopra no tempo certo o instrumento e com seu som toca "agora ao ataque!", "agora à retirada!", embora muitos soldados possam não obedecer a seus sinais ${ }^{4}$.

Quando a alguns lhes estorva o medo, quando a ambição detém a outros como que por grilhões, quando o ouro e os presentes fazem que a muitos lhes suma a língua e feche a boca, certamente esta disputa se prestará a pelo menos um fim: que todos entendam não faltar no povo alguém que, do seu retiro, defenda a verdade e indique os males e os perigos que publicamente nos ameaçam, salvo se confron-

${ }^{3}$ LUCIANO. Diálogo dos Mortos. Trad. Américo da Costa Ramalho. Brasília: Editora UnB, 1998.

${ }^{4}$ Ez 33,4. tados a tempo. De fato, com Diógenes sairei a público e agitarei minha barrica; externarei o que sinto, qualquer que seja o resultado. Talvez nossa diligência tenha algum proveito, visto que em todos há o desejo da verdade e a preocupação de ajudar. Que este ensinamento seja recebido com bons olhos; foi empreendido com espírito sincero. Para que isto ocorra, rogo à Majestade Celeste, à Majestade terrena, que é sua vigária, e a todos os cidadãos do Céu. E aos homens de toda e qualquer condição e dignidade imploro que, antes de condenar nosso esforço ou tecer juízo sobre qualquer de suas partes, tenham lido atentamente esta folha e avaliado a querela de que tratamos, segundo o meu alvitre a mais grave de todas as que afligiram este reino em muitos anos.

\section{Capítulo I \\ Se o Rei é Dono dos Bens que os Súditos Possuem}

Muitos são os que exageram o poder do rei para além do que o permitem a razão e a equidade. Uns para cair nas boas graças do Príncipe e assim acumular fortunas privadas; nenhuma atenção dá à honestidade esse gênero pernicioso de homens, sempre a frequentar as cortes dos príncipes. Outros estão persuadidos de que assim aumentam a majestade real, porque nela se encontraria certamente a salvaguarda do bem-estar público. Nisto se enganam e erram. Assim como nas demais virtudes, também no poder há certos limites que, uma vez desrespeitados, não o fortalecem, mas o debilitam totalmente e o fazem desfalecer. Como o dizem homens sensatos, o poder não é como dinheiro e tesouros, que quanto mais alguém os acumula, mais rico e feliz se torna; é antes como o alimento em relação ao estômago: este, tanto desprovido de alimento, quanto cheio para além do suficiente, geme e sofre de igual maneira.

Com o aumento do poder régio para além dos limites, é certeira a degeneração a uma tirania, tipo de principado não apenas vicioso, mas também débil e nada duradouro, uma vez 
ofendidos seus súditos e inimigos (a cujo furor nenhuma força, nenhuma arma resiste). Que o rei não é dono dos bens que privadamente possuem os súditos, e tampouco está sob seu arbítrio invadir as casas e terras dos cidadãos, nem tomar e confiscar o que lhe dê na vontade, declara-o a própria natureza do poder régio nascida da república, se for legítima e justa.

Como diz Aristóteles (384-322 a.C.), os reis primeiro foram postos em eminência para que, na guerra, os cidadãos se protegessem contra a tormenta de inimigos que avançava, convocando-se o povo sob um estandarte. Desta posição deu-se um passo adiante, e lhes foi concedido, em tempo de paz, o poder de dar castigo aos criminosos e de dirimir com autoridade todas as querelas entre os populares. Para tutelar dignamente tal autoridade, designou-se certa renda, com a qual se sustentasse a vida do príncipe; também se determinou a forma de realizar este pagamento. Isto dá ao rei o domínio sobre a renda que lhe atribuiu a república e sobre outros bens que, ou já possuía antes de ser rei, ou que (já rei) tivesse recebido do povo - mas não lhe dá domínio sobre o que os cidadãos retiveram para si, pública ou privadamente. Nem o poder dado em guerra ao comandante, nem a autoridade de governar os súditos lhe outorgam a faculdade de lançar-se sobre os bens de cada um.

Por isso, nas Novelas ${ }^{5}$ - naquela que começa com Regalia, ${ }^{6}$ na qual se descrevem

\footnotetext{
${ }^{5}$ Assim se tomou por hábito denominar em português as Novellae Constitutiones, adições de Justiniano (482-565) posteriores à segunda edição de seu Codex (que por sua vez compunha o Corpus Iuris Civilis). Promulgadas desde 534 até a morte do imperador, só foram compiladas postumamente. As edições medievais consistiam ou nas Autênticas (nas quais se encontrava uma confiável compilação de 134 novelas encontrada em Bolonha no ano de 1100), ou numa coleção de 168 novelas pouco posterior, que incluía manuscritos de Veneza (século XII) e Florença (século XIV), e se tornou a base para edições modernas como a seguinte: SCHÖLL, R. \& KROLL, W. Novellae - Recognovit Rudolphus Schoell - Opus Schoelli morte interceptum absolvit Guilelmus Kroll - Corpus Iuris Civilis vol. III. Berlim [várias edições].

' O referido capítulo que se inicia com "Regaliae..." (ou seja, "regalias") não pertence propriamente às
}

todos os privilégios do rei - não está contido tal domínio. Em verdade, se estivessem sob arbítrio do rei os bens de todos os súditos, o que foi feito por Jezabel ao ocupar a vinha de Nabot não haveria sido tão repreendido; estaria ela exercendo os direitos de seu marido (que certamente era rei), e reivindicando o que era seu. Mais ainda: Nabot teria sido acusado de contumácia, por haver-se recusado injustamente a entregar o que era devido. Mas a comum sentença dos jurisconsultos-conforme explicitada no Código, em Si contra ius vel utilitatem publicam, última lei ${ }^{8}$, citada por Panormitano ${ }^{9}$ no capítulo Quanto, em De Iureiurando - é a de que, sem consenso do povo, os reis nada

Novelas de Justiniano, mas aos Libri Feudorum (Livros dos Feudos), um registro escrito dos costumes feudais, provavelmente do século XII, e que a partir do século seguinte começou a ser agregado ao Corpus Iuris Civilis. Refere-se ao Livro II, tít. 56, "Quid sint Regaliae".

${ }^{7}$ Ver: 1 Rs 21.

${ }^{8}$ Codex, I, tít. 22 n. 6.

9 Niccolò Tedeschi (1386-1445), também conhecido como Abbas Panormitanus (ou seja, "Abade de Palermo"), foi um canonista beneditino excepcionalmente prolífico, e um dos maiores de sua época. O autor refere-se ao Lectura Super Quinque Libros Decretalium, comentário do Panormitano à compilação de decretais de Gregório IX (1170-1241). A seção de nome Quanto corresponde a Livro II, tít. 24 cap. 18. Os capítulos eram nomeados conforme a primeira palavra de cada uma das decretais; neste caso, trata-se de uma epístola do papa Inocêncio III (1161-1216) a Jaime I (1208-1276) de Aragão, acerca da moeda em seu reino: "Quanto personam tuam...". [Curiosamente, o latim original de Juan de Mariana registra de modo correto "Quanto" como nome do capítulo, embora a tradução ao castelhano (Obras completas del padre Juan de Mariana. Madrid: Rivadeneyra, 1854. Vol. II, p. 577-91), nos traga "Quarto" (ou às vezes "Quinto", indistintamente). Tendo em vista que tal tradução é atribuída ao próprio autor, é compreensível que se a tenha acatado na versão inglesa (A Treatise on the Alteration of Money. Trad. Patrick T. Brannan. Grand Rapids: Christian's Library Press, 2011). Não obstante, nem no Panormitano, nem em Henrique de Susa (1200-1271), o cardeal Hostiense, nem em Inocêncio IV (1195-1254) esta seção corresponde a tais ordinais, e nenhuma delas tem ordinais como identificadores. Tal imprecisão nos leva a suspeitar que a tradução tenha sido feita sob a supervisão de Juan Mariana, mas talvez não de próprio punho]. 
podem sancionar em detrimento dos súditos; e é especialmente nefasto que subtraiam bens (ou partes de bens) e os revertam à pessoa régia. De fato, não seria lícito levar aos tribunais um litígio contra o príncipe - nem designar-lhe uma data - se todas as coisas estivessem realmente sob seu poder e direito. Se subtraísse um bem de alguém, a resposta seria imediata: ele o fez não injustamente, mas por estar no seu direito. Tampouco pagaria um preço por terras ou imóveis privados quando deles necessita, mas antes tomaria essas coisas como suas.

Seria ocioso expor com mais exemplos este ponto manifesto, que nenhuma mentira fará ruir. Nenhuma bajulação pode fazer da luz a noite. É próprio do tirano não pôr limites a seu império e julgar que tudo é de direito seu. Ao contrário, o rei põe moderação ao seu poder, refreia a cupidez, define a justiça e a equidade, e não as transgride. Ele estabelece que os bens dos cidadãos privados estão sob sua confiança e tutela, e nada lhes subtrai, exceto talvez segundo o regulamento e forma das leis.

\section{Capítulo II \\ Se o Rei Pode Impor Tributos aos Súditos SEM SEU Consentimento}

A alguns parece grave e incompatível com a majestade que as riquezas de um rei dependam da vontade do povo, de modo que ele não lhes possa impor tributos, exceto com seu consentimento. Isto seria fazer que o árbitro e moderador das coisas não fosse o rei, mas os súditos. E prosseguem afirmando que a convocação das cortes quando da imposição de novos tributos se deve à modéstia do príncipe, o qual por sua vontade teria o poder de fazê-lo sem consulta aos súditos, mas conforme a necessidade das coisas e a escassez do erário. Decerto estas são palavras lisonjeiras, gratas aos ouvidos dos regentes, e que às vezes induziam ao engano príncipes vizinhos; vejamos a França, por exemplo.
Como o atesta Filipe de Comines (14471511), na biografia de Luís XI (1423-1483), rei de França, o primeiro monarca a seguir este raciocínio foi Carlos VII (1403-1461), seu pai e antecessor. Oprimia-o uma pobreza especialmente severa na parte da nação ocupada pelos ingleses. Aplacados os nobres, aos quais concedeu pensões anuais, oprimiu o resto do povo com novos tributos, conforme desejava. Diz-se que desde então os reis de França têm acedido a seus direitos como se não lhes existisse a tutela do povo. E esta é realmente uma ferida que receberam por haver ofendido seus súditos, chaga que tantos anos não sanaram e, como o diz aquele mesmo biógrafo, sangra até os dias de hoje. Eu diria mais: as próprias guerras civis francesas que vigoraram por tantos anos de nossa época não tiveram outra causa. Pois um povo oprimido - em grande parte sem lar, sem patrimônio familiar, despojado de bens - consentiu em tomar armas na intenção de destruir ou ser destruído, de dar fim a seus males com a morte, ou, se vencesse, de tomar para si os despojos, desejoso de riquezas e bens. E, para que o fizesse mais facilmente, recobriu a obstinação com o véu da religião, a perversidade com a honradez; e disto surgiram inúmeros males.

Em Castela, decerto seria pouco eficiente convocar uma corte de procuradores das cidades, pois poucos deles são idôneos para gerir estes temas. São levados pelo acaso, homens levianos de caráter venal, que nada mais têm diante dos olhos senão o desejo de merecer as graças do príncipe à custa da calamidade pública, para disto extrair lucro. Somem-se a isso as maquinações dos cortesãos, que às promessas mesclam súplicas e ameaças que arrancariam da terra até os cedros do Líbano e os tombariam. A ninguém resta dúvida: como estão as coisas, tais pessoas certamente jamais se oporiam à intenção do príncipe de que se acate tudo o que ele desejar. Seria mais sensato que esta gente jamais se reunisse, para não dar escusa a gastos inúteis e corrupções várias.

Aqui porém não nos ocupamos do que ocorre, mas do que a razão nos exige ocorra: 
que novos tributos apenas sejam impostos com o livre consentimento do povo, não por força, imprecações ou ameaças. Como nos alerta aquele mesmo historiador, o povo deve mostrar-se dócil e não rechaçar a vontade do príncipe, mas antes acudir virilmente à pobreza do erário, conforme for preciso. Mas também devem ser pacientes os ouvidos do príncipe; ele deve escutar o povo e considerar diligentemente se suas forças e riquezas estão à altura de arcar com novo ônus, ou se podem encontrar-se outros meios para sanar a escassez - mesmo que o príncipe deva ser seja chamado à modéstia e ter restringidos os seus gastos supérfluos, o que antigamente se fazia nas cortes do reino.

Seja então estabelecido que nunca é lícito ao príncipe oprimir seus súditos com novos ônus, a não ser que obtenha o consentimento daqueles a quem isto diz respeito, ou seja, ao menos os líderes do povo e a república. Isto se confirma abundantemente pelo que antes dizíamos: os bens privados dos cidadãos não estão sob o arbítrio do rei. Ele não os tomará, nem no todo nem em parte, exceto por vontade dos que os têm por direito. Ademais, se - por pronunciamento dos jurisconsultos - nenhum rei pode estabelecer uma perda aos cidadãos privados se estes a recusam, tampouco poderá tomar parte de seus bens mediante novo tributo que concebeu e impôs. Por quê? Porque nem a condição de comandante nem a de governante lhe concedem esta faculdade. Ao contrário, se o príncipe recebeu da república o poder - com rendas específicas mediante as quais se garante seu sustento - e tem o desejo de elevar tais valores, apenas satisfará suas atribuições se solicitá-lo ante aqueles que em princípio definiram tais rendas com números precisos. Caberá a eles, segundo lhes pareça, conceder ou negar o que se lhes pede.

Se noutras nações se age de modo distinto, ao menos na nossa isto foi proibido por lei, promulgada em 1329 por Afonso XI (1311-1350), rei de Castela, nas Cortes de Madri, em resposta às súplicas populares, conforme a petição 68 , de que nunca se imponha tributo à nação contra a vontade do povo. Reza a lei: "Em súplica me foi pedido que não se imponha tributo extraordinário, nem público, nem privado, sem antes haver-se convocado a nação em assembleia, e obtido a concessão de todos os procuradores das cidades que se tiverem apresentado. $A$ isto respondemos: isto nos agrada, e estabeleço que assim seja". No lugar já citado, Filipe de Comines repete duas vezes em francês as seguintes palavras: "por isso, dando prosseguimento à questão, não há nenhum rei ou príncipe em todo o mundo que possa exigir de sua nação um só maravedi $i^{10}$ contra a vontade daqueles que deve representar, sem assim praticar violência e tirania". Pouco depois o autor agrega: "Além de praticar tirania, incorre na sentença de anátema o rei que agir de outra maneira", o que para mim parece dizer respeito ao sexto capítulo da bula In Coena Domini, a qual pune com exclusão dos ritos cristãos quem, no governo, impuser novos tributos. Neste ponto, algumas bulas contêm: "Salvo se para isto tiver autoridade", e outras: "Salvo no caso de que isto tenha sido concedido mediante direito $e$ leis"11. Que outros julguem se os reis que agem de modo contrário se eximem desta execração;

${ }^{10}$ No original em latim: quadrans. O quadrante foi uma das menores moedas romanas, equivalente a um quarto de asse. Em sentido etimológico e lato, "quadrante" indica qualquer quarta parte de uma medida, mas não há emprego monetário para este termo fora do contexto romano. Neste tratado, o autor muitas vezes empregará quadrans e "maravedi" indistintamente ("... maravedinos seu quadrantes..."), e ademais o faz neste ponto de sua própria tradução. O maravedi de cobre era a segunda menor moeda de Castela.

${ }^{11}$ A bula In Coena Domini, promulgada inicialmente em 1363 e abolida em 1770, era constantemente atualizada e consistia sobretudo numa lista de artigos que descreviam atividades resultantes em excomunhão. Ao menos segundo a edição de 1580, a referida sentença se encontra no artigo quinto: "Também excomungamos e anatematizamos a todos os que em suas terras imponham novos pedágios ou impostos [gabellas] sem que para isto tenham poder, assim como aqueles que exigem impor ou elevar estas coisas proibidas" [A propósito: ocasionalmente, o leitor encontrará pequenas discrepâncias entre as numerações citadas pelo autor e sua efetiva localização nas obras às quais pudemos aceder, o que se deve certamente à variação nas edições. Na impossibilidade de aferir exatamente quais delas o autor consultou, indicaremos o ponto correspondente numa edição específica à qual o leitor possa aceder]. 
para nós não pareceriam eximir-se, pois nem têm poder para agir de modo distinto, nem isto lhes foi concedido por direito. E, visto que Filipe de Comines foi um secular, e não um homem de letras ${ }^{12}$, o que ele deixou afirmado com tamanha asseveração certamente foi o sustentado pela autoridade dos teólogos daquele tempo, que em seus pareceres não discrepavam neste tema.

Eu próprio acrescento que, se não tem o consentimento do povo, o monarca será réu de tal delito e castigo, não apenas quando assim impõe sua vontade a título de tributos, mas também sob o artifício de um monopólio. Pois, decerto, esta será também uma fraude (embora sob outro nome) por meio da qual uma pessoa é subtraída do que lhe pertence: para que, vendidas as coisas por preço mais alto do que o justo, se leve ao erário parte do dinheiro dos súditos, sem nenhuma autoridade para tanto.

É fato que há alguns anos o príncipe introduziu na nação certos monopólios sobre jogos de azar, sublimados corrosivos e sal ${ }^{13}$. Não me refiro a estes; em verdade, julgo-os instituídos prudentemente. No que se refere à probidade e à boa religião do príncipe, deve-se crer que com tais monopólios nada fez que exorbitasse a razão e as leis. Apenas defendo que os monopólios não se distinguem de tributos e é necessário ter idêntica cautela de instituí-los regradamente, e com igual consentimento do povo. Este tema se esclarecerá com um exemplo. Em Castela tem-se pretendido exigir um imposto público sobre a farinha, pois a nação tem sido oprimida por grandes dificuldades. Se, instituído um monopólio, fosse então lícito ao monarca comprar todo o trigo do reino e vendê-lo por preço mais alto, seria ocioso e sem sentido que a imposição de um tributo dependesse da vontade do

$12 \mathrm{O}$ original latino traz o termo expers (desprovido, carente), não expertus, pois Mariana realmente, na tradução castelhana, descreve aquele cronista não como homem de letras (dada a sua condição de secular), mas como fiel compilador de sabedoria e autoridade alheias.

${ }^{13} \mathrm{O}$ autor aqui se refere a Filipe II (1527-1598) da Espanha, monarca anterior ao já citado Filipe III. povo - visto que o rei poderia conseguir o que quer mediante monopólio, com lucro igual ou ainda maior. Disto depreendemos certamente que, se ao rei não é lícito impor novos tributos, tampouco o será instituir monopólios de mercadorias sem a consulta e a aprovação do povo ao qual se aplicam.

\section{Capítulo III \\ Se o Rei Pode Desvalorizar a Moeda Alterando-a em Peso ou Qualidade, sem Consulta ao Povo}

Duas coisas aqui são evidentes. Primeiro, que está sob arbítrio do rei alterar a moeda segundo a forma e a imagem nela expressa, desde que não reduza seu valor (Assim interpreto os jurisconsultos, quando concedem ao rei o poder de alterar a moeda). As casas da moeda estão no direito do rei, que nelas tem livre administração. Também na lei Regalia lista-se a moeda como um dos direitos do rei. Logo, não havendo detrimento dos súditos, que ele institua o modo de cunhagem que mais lhe agrade.

Segundo, se por sítio ou por guerra o rei for forçado por alguma escassez, concedemos que ele possa desvalorizar a moeda sem consentimento do povo, desde que a desvalorização não se estenda para além do período de escassez, e que em tempo de paz se recompensem em plena fé aqueles que sofreram prejuízo.

Durante um inverno rigorosíssimo, Frederico II (1194-1250) da Germânia sitiava a cidade de Faenza. Os sitiados nada faziam, o sítio avançava, e faltou dinheiro para os salários. O monarca mandou cunhar moedas de couro, com sua efígie num lado e a águia do império no outro, que valiam uma peça de ouro cada. Fê-lo por seu próprio desígnio, sem qualquer assembleia do império. O plano salutar deu fim ao problema: aplacados os soldados mediante este artifício, ele dominou a cidade. Finda a guerra, ele trocou em plena fé as moedas de couro pelo mesmo número de 
moedas de ouro. Assim nos relata Aragones y Pandolso Colenúcio, em sua História de Nápoles, livro IV. Também na França cunharam-se ocasionalmente moedas de couro, ornadas com um pequeno prego de prata. E, quando esteve sitiada a cidade holandesa de Leida, nela se fez dinheiro de papel, como relata Reinier Budélio em De Monetis I, cap. 1 n. 34.

Estes fatos são evidentes. $O$ que se discute é se o príncipe pode, fora de situações excepcionais, sanar a pobreza do erário por autoridade própria e adulterar a moeda, seja em seu peso (subtraindo-lhe uma parte), seja em sua qualidade. O parecer comum dos jurisconsultos está, sem dúvida, em concordância com o do Hostiense, no título De Censibus ${ }^{14}$; dentre eles tanto Inocêncio $\mathrm{IV}^{15}$ quanto o Panormitano, no capítulo Quanto (no título De Iureiurando), indicam que o príncipe não o pode fazer, exceto com o consentimento dos súditos. Disto que foi dito, vê-se que, se o rei não é dono, mas administrador dos bens que os súditos possuem em privado, ele não lhes poderá subtrair nenhuma parte por sua mera vontade, nem desta maneira, nem de outra.

Isto ocorre toda vez que se desvaloriza a moeda: pois dá-se por maior preço o que vale menos. Ora, se o príncipe não pode impor tributos a súditos que não os aceitam, nem instituir monopólios sobre mercadorias, então tampouco poderá captar novos lucros mediante adulteração de moeda. Pois estas artes têm um só e mesmo fim: limpar os bolsos do povo para amontoar no erário o dinheiro da nação. Não te deixes levar pelos disfarces e artimanhas de uma lei que dá ao metal valor maior que o que tem por natureza e avaliação comum. Isto não ocorrerá sem grande ruína para todos. Não importa a arte ou o estratagema: derramado o sangue, o corpo sem dúvida se debilita e desfalece.

${ }^{14}$ HENRIQUE DE SUSA. Apparatus Super Quinque Libris Decretalium. III, tít. 39.

${ }^{15}$ Também Inocêncio IV havia comentado as decretais de Gregório IX, em seu Super Libros Decretalium. O capítulo Quanto, como dissemos, corresponde à glosa sobre a carta de Inocêncio III, em: Decretales, II, tít. 24 cap. 18.
Assim, tampouco poderá o príncipe captar lucro sem a dor e o gemido dos súditos. Donde sai o lucro para um, dali o prejuízo para outro, como nos recordam haver dito Platão (427-347 a.C.). Nenhum esforço pode destruir estes fundamentos da natureza.

Assim o vejo no capítulo Quanto em De Iureiurando, quando Inocêncio III julga inválido o juramento pelo qual Jaime I, o Conquistador, rei de Aragão, obrigara-se a preservar por algum tempo a moeda cunhada por seu pai, Pedro II (1178-1213), em qualidade mais baixa que a de antes. Entre outros, afetava esta causa o consentimento do povo, que fora ignorado. Tanto Inocêncio IV quanto o Panormitano, ao explicar o que foi dito acima, confirmam que o príncipe não está na posição de estabelecer algo que resulte em prejuízo para o povo (Dizemos haver prejuízo quando se subtrai alguma parte do seu patrimônio). E desconheço como aqueles que o fazem poderiam evadir-se da excomunhão e da censura promulgadas por todos os anos na bula In Coena Domini, se, como dissemos ao tratar dos monopólios, estes artifícios - seja como for que os dissimulem - têm todos o mesmo fim: atribuir ao povo novos ônus e acumular dinheiro, o que é ilícito. E se alguém alega que, desde a antiguidade, foi concebido a nossos reis, por negligência e resignação do povo, o poder de alterar a moeda segundo sua vontade, ao menos eu não encontro nenhum vestígio deste costume e permissão. Ao contrário, vejo que as leis monetárias de Fernando II (1452-1516) de Aragão (o Rei Católico), de Filipe II (seu bisneto) e dos reis anteriores sempre foram todas aprovadas junto à nação nas cortes.

\section{Capítulo IV O Duplo Valor do Dinheiro}

É duplo o valor do dinheiro: um é intrínseco e natural, proveniente da condição do metal e seu peso, aos quais se agregaria o trabalho de cunhá-lo e o aparato para fazê-lo, o qual tem um custo. O outro se diz legal e extrínseco, constituído pela lei do príncipe, pela 
qual se estabelecem os valores monetários, assim como os preços das outras mercadorias. Numa república bem constituída, aqueles que detêm o poder devem cuidar para que estes dois valores sejam idênticos e não discrepem entre si. Pois, assim como no caso das outras mercadorias seria injusto estabelecer que vale dez aquilo que - por si e por avaliação comum - vale cinco, assim também será, no caso do dinheiro, se o valor legal exorbitar. Entre outros autores, também Budélio - em seu De Monetis I, n. 7 - trata de explicar que todos julgam, em uníssono, ser ridículo e pueril opinar em sentido oposto. Se, ao contrário, é lícito desvincular estes dois valores, que façam dinheiro de couro, de papel ou de chumbo (como sabemos ter sido feito em situação de necessidade), pois o resultado será o mesmo, e o custo da cunhagem será menor do que se o fizerem com cobre.

Não sou da opinião de que o príncipe deva cunhar a moeda às suas próprias expensas. Ao contrário, parece-me justo adicionar algum valor à avaliação do metal, por conta do trabalho de cunhagem e de todo o serviço monetário. Tampouco me parece inconveniente que se agregue um pequeno lucro, em sinal da soberania e prerrogativa do príncipe, para recompensar sua administração - conforme descrito na lei promulgada em Madri, em 1566, acerca da cunhagem das moedas de prata chamadas cuartillos. Também Inocêncio IV indicava aprovar tal posição, no capítulo Quanto (De Iureiurando), embora não seja explícito.

Mas defendo que estes dois valores deveriam precisa e diligentemente igualar-se, e isto se depreende do que dizia Aristóteles $^{16}$ no início, os homens trocavam entre si as próprias coisas. Em seguida, por opinião comum, pareceu melhor que as mercadorias fossem trocadas por metais como ferro e ouro, para evitar dispêndios e aliviar o incômodo de trazer de lugares distantes as mercadorias tidas por ambas as partes como estorvadoras e impeditivas. Assim,

\footnotetext{
${ }^{16}$ ARISTÓTELES. Política. I, 6 c.3, 12ss [1257a 17ss].
}

uma ovelha era trocada por tantas libras de cobre, um cavalo por tantas de prata. Mas era difícil pesar estes metais com precisão. Portanto, a autoridade pública determinou que nas peças de metal se marcasse seu peso, para a comodidade do comércio. Este é o uso principal e legítimo do dinheiro, embora o tempo e a malícia tenham introduzido fraudes e artimanhas alheias ao seu emprego salutar.

Pondo de lado as leis da antiguidade, também nas nossas houve claramente o propósito de que estes dois valores se mantivessem igualados. No caso da prata e do ouro, disto não há dúvida. De oito onças ${ }^{17}$ de prata (ao que chamamos um "marco"), fazem-se ao menos 67 moedas de prata ${ }^{18}$, ao passo que o mesmo peso de prata bruta se troca por 65 moedas de prata, estando ambos os casos sob os preceitos da lei. Vê-se que, pelo trabalho de cunhagem, se adicionam duas destas moedas. E, embora cada moeda de prata valha 34 maravedis, tire-se da prata a marcação e ela valerá aproximadamente 33. Que dizer do ouro? De um marco de ouro cunham-se 68 moedas às quais chamamos coronas; este peso em ouro bruto vale quase o mesmo.

${ }^{17}$ No original em latiem bes. No antigo sistema romano, em que a libra se dividia em 12 onças (unciae), um bes - que em si significa "dois terços" de qualquer medida - equivalia a oito onças. Embora no sistema de pesos de Castela a libra tivesse 16 onças, ainda assim o autor usa o latim bes para referir-se a oito onças, ou seja, à sua metade, o marco. Visto que o emprego do referido termo apenas serviu para significar "marco", assim o traduziremos nas próximas vezes. [Nesta tradução, não nos pareceu desejável qualquer conversão para o sistema métrico. Primeiro, porque nas conversões se perderia a riqueza vocabular da obra e seu contexto histórico. Segundo, porque o peso da libra sofreu variações ao longo do tempo e, embora seja relativamente certo que a libra de Castela tenha equivalido a $460 \mathrm{~g}$, não seria prudente presumir que ela mantivesse este exato peso ao longo dos séculos estudados por Juan de Mariana. Terceiro (e principalmente), porque a conversão para gramas (ou libras inglesas, ou qualquer outro sistema atual) não nos traria nenhum valor adicional ao itinerário argumentativo do autor].

${ }^{18}$ Estas eram chamadas de reais (reales) de prata. 
Isto também se dá nas moedas de cobre ${ }^{19}$, nas quais é um pouco mais difícil aferir como o valor natural integra o legal. Em 1497, em Medina del Campo, os Reis Católicos determinaram por lei que, de um marco de cobre, ao qual se mesclariam sete grãos de prata (isto é, o peso de uma moeda e meia de prata), far-se-iam 96 maravedis. A prata valia mais que 51 maravedis. As oito onças de cobre e o trabalho de cunhagem valiam ao menos outros 40 maravedis do valor a igualar. Vemos que o valor legal facilmente se compunha com o do metal e o do trabalho.

Depois, em 1566, Filipe II anulou a lei anterior e estabeleceu que a oito onças de cobre se mesclariam quatro grãos de prata (o exato peso de uma moeda de prata); e disto se cunhariam 110 maravedis. Deste modo, ele subtraiu pouco mais de meia moeda de prata da qualidade do metal e ainda agregou 14 maravedis ao antigo valor. Certamente pareceu-lhe, creio, que os custos de cunhagem duplicaram de uma época para a outra; ademais, ter-se-ia obtido certo lucro por sua administração. Seduzidos pela módica e tênue expectativa (advinda do poder real) de cunhar a moeda com tal custo, muitos mortais terminaram por acumular grande fortuna; assim como nos anos anteriores, esta negociação foi tida como especialmente rentável. Mas ainda assim os dois valores não discrepavam muito entre si: pois ao marco de cobre estava somado o valor de uma moeda de prata, e a isto se agregam a estimativa do próprio cobre e a da cunhagem - que, juntas, sem dúvida somavam ao menos outras duas moedas de prata, especialmente porque era também comum que se cunhassem moedas ínfimas, chamadas blancas, com valor de meio maravedi, para muito maior incômodo e aborrecimento.

Na moeda de cobre que se cunha neste momento não se mescla nenhuma prata, e de oito onças de cobre se produzirão 280 mara-

\footnotetext{
${ }^{19}$ Como o leitor verá, não se trata propriamente de moedas de cobre puro, mas de liga de cobre e prata (em castelhano, vellón), as quais gradualmente terão reduzida - e em alguns casos eliminada - sua proporção de prata.
}

vedis. O custo de toda a marcação não excede a uma moeda de prata, e o cobre se adquire a 46 maravedis. Estes valores, combinados, somam portanto 80 maravedis ${ }^{20}$. Logo, vão ao erário 200 maravedis pelos quais o valor legal supera o valor intrínseco e natural da moeda - com enorme perigo para a república, o qual nos empenharemos agora em explicar.

Primeiro, isto repugna à concepção primária e natural do dinheiro, como já foi explicadoacima.Segundo, istoem nada ajudará a evitar que gente de toda parte, seduzida pelo prospecto de enorme lucro, adultere a moeda em condições semelhantes. Por último, estes valores se igualarão, quando no comércio o povo recuse dar e receber mais dinheiro do que ele vale naturalmente. Ficções e fraudes logo desmoronam, uma vez detectada sua arte, e o príncipe que lutar contra isso nada alcançará. E poderá fazer que trajes toscos se vendam como veludos de seda? E vestes de lã, como de ouro? É claro que não, por mais que o tente, ainda se isto fosse permitido pelas leis e conforme à justiça. Na França, muitas vezes os reis fizeram soldos de qualidade inferior, e logo nossas moedas de prata passaram a valer mais: na época em que vivíamos naquele reino, o que antes se estimava em quatro soldos passou rapidamente a valer sete ou oito soldos. Pois se o valor legal do dinheiro não decresce, certamente as mercadorias todas subirão de preço, na exata medida em que do dinheiro se subtraiu qualidade ou peso. $\mathrm{E}$ a isto não se poderá resistir com nenhuma arte: tudo retorna ao mesmo ponto, ou seja, o de que este dinheiro valerá menos do que aquele, anterior e melhor - como em seguida se verá.

\section{Capítulo V \\ Os Fundamentos do Comércio: Moeda, Pesos e Medidas}

Os fundamentos do comércio, aquilo no qual se apoia toda a estrutura mercantil, são

\footnotetext{
${ }^{20}$ Uma moeda de prata (com quatro grãos do metal) valia 34 maravedis.
} 
certamente os pesos, as medidas e o dinheiro. Muitas coisas se vendem por peso e medida, mas todas por dinheiro. No que tange a isto, assim como estão todos convencidos de que uma construção deve ter fundamentos imóveis e intactos, o mesmo vale para pesos, medidas e dinheiro: estes não mudam sem perigo e detrimento para o comércio. Assim o viam os antigos, pois com isto tinham grande cuidado, e guardavam exemplares de todas estas coisas em seus mais sagrados templos, para que ninguém desatinadamente os adulterasse. Assim narra Fânio, em seu livreto De Ponderibus et Mensuris, e este tema consta na lei de Justiniano (Autênticas, De Collationibus Aeris) ${ }^{21}$. Também das palavras em Levítico 27,25 (“Toda avaliação será feita em siclos do santuário..."), alguns deduzem ter havido entre os judeus o hábito de preservar no templo um siclo com o peso de quatro dracmas, para que, sendo fácil o recurso a um siclo legítimo, ninguém ousasse adulterar a moeda por subtração de peso ou qualidade. Foi de tão grande importância preservar intactas estas coisas, que não se julgava supérfluo nenhum cuidado. Também segundo o próprio Santo Tomás de Aquino (1225-1274), a moeda não deveria ser mudada à toa ou à mera vontade do príncipe ${ }^{22}$.

Por isso recebeu críticas a alteração do azumbre (uma medida de líquidos) que se fez em Castela nos últimos anos, pela qual se exigia novo tributo sobre óleo e vinho não sem algumas queixas do povo. Pois, além de outros incômodos, surgiu a necessidade de comparar as medidas recentes com as antigas, as nossas com as estrangeiras; uma nova confusão. Desta feita, parecem pouco eruditos aqueles com quem está o governo das coisas, pois não atinam com os males e perturbações que, em nossa gente e entre os estrangeiros, comumente emanam desta

\footnotetext{
${ }^{21} \mathrm{O}$ De Collatione Aeris se encontraria mais propriamente no Codex (X, tít. 29), e determinava relações de valor entre pesos de ouro e cobre para a contribuição ao fisco.

${ }^{22}$ De Regimine Principum. II, 14 . O referido capítulo já consiste na continuação dada por Ptolomeu de Lucca (1236-1326) ao De Regno do Aquinate.
}

fonte. Era fácil perceber que a desvalorização da moeda seria algo rentável ao monarca, e consta que muitas vezes os antigos foram levados à fraude por esse anseio. Mas logo puderam dar-se conta dos infortúnios nos quais em seguida precipitaram-se, uma vez feita esta alteração.

Para remediar tais problemas, foram frequentemente necessários novos e maiores males, que em seu lugar serão explicados. Mas a situação não é distinta à de uma bebida dada fora de hora a um homem doente: no primeiro momento, reaviva-o, é quase uma mudança de vestes; mas depois aumenta as causas da doença, faz crescer o ardor da febre. Para que se entenda quanto cuidado já se teve para que não fossem abalados estes fundamentos do convívio humano, explicamos em nosso De Ponderibus et Mensuris (cap. 8) que a onça romana se manteve imutável e ainda é a mesma que a nossa. Dos outros pesos é necessário reconhecer o mesmo: os nossos não devem discrepar dos antigos.

\section{Capítulo VI \\ A Moeda foi Constantemente Alterada}

É opinião comum entre os judeus que as moedas, medidas e pesos do santuário fossem o dobro dos comuns: o bato, o gomor, o siclo, etc. A razão disto foi sobretudo que a diligência em preservar as medidas e pesos do santuário não pôde impedir que o povo, por variadas circunstâncias, as diminuísse e as fizesse menores que sua metade. Por isto, nos antigos escritores conciliam-se passagens que parecem discrepar entre si ou contrariar a Sacra Página. Consta entre os romanos - e o atesta Plínio (23-79), o velho, em Historia Naturalis XXXIII, cap. $3^{23}$ - que o asse era uma moeda de cobre no valor de quatro quadrantes dos nossos tempos (ou seja, quatro maravedis) ${ }^{24}$.

\footnotetext{
${ }^{23}$ Mais precisamente, cap. 13.

24 Recordamos que, no sistema monetário romano, o quadrante (quadrans) equivalia a um quarto de asse. A tradução de quadrans como "quadrante" ou
} 
Cunhado inicialmente com o peso de uma libra, por pressão da primeira Guerra Púnica foi reduzido a duas onças, e foi chamado asse sextantário - ou seja, que pesa a sexta parte de uma libra, a qual na época era de 12 onças, tal como as libras italiana e francesa dos dias atuais. Pressionados novamente pela guerra contra Aníbal, os romanos reduziram o asse à duodécima parte do original, e posteriormente a redução chegou ao peso de meia onça.

O denário, com valor de 40 quadrantes, era no início cunhado com prata pura. Em seguida teve sua qualidade alterada por Marco Lívio Druso (†91 a.C.), o tribuno da plebe, que lhe agregou um oitavo de cobre, como o afirma Plínio, o velho, no mesmo capítulo. Em tempos posteriores, mais cobre foi mesclado, e hoje se desenterram não poucos denários de prata de qualidade muito inferior, devido a um acréscimo de cobre de até mais de um terço do peso. Também a moeda de ouro era de particular qualidade e pesava dois dracmas no tempo dos primeiros imperadores; pouco depois, com apenas uma onça de ouro cunhavam-se seis delas, chamadas soldos (Pesam aproximadamente o nosso castellano). Isto consta da lei de Justiniano, no capítulo De Susceptoribus, Praepositis et Arcariis, capítulo Quotiescumque ${ }^{25}$.

Plauto (254-184 a.C.), que em sua antiguidade foi um vate sobre tal desmando de inovações, parece censurar num de seus prólogos a desvalorização da moeda pelos romanos, quando diz:

Julgo sábios os que usam vinho velho,

Pois estas novas comédias hoje feitas

São muito piores que as moedas novas ${ }^{26}$.

Também as moedas que chegaram aos nossos dias são indício de que nelas os romanos fizeram alterações constantemente. $\mathrm{E}$ consta da memória recente que o mesmo tem sido feito por todos os povos. Os príncipes, com ou sem o consentimento dos súditos,

"maravedi", como vimos em nota anterior, guia-se sobretudo pelo contexto.

${ }^{25}$ Codex, X, tít. 70 n.5.

${ }^{26}$ PLAUTO. Casina. Prólogo, 5-7. frequentemente viciaram a liga da moeda, ou extraíram parte de seu peso. Seria supérfluo requerer exemplos estrangeiros, se ante eles abundam amplamente os domésticos. No capítulo 14 da história de Afonso $\mathrm{XI}^{27}$, rei de Castela, afirma-se que a moeda fora alterada por Fernando III (1201-1252), o Santo, por seu filho Afonso X (1221-1284), o Sábio, por Sancho IV (1258-1295), o Bravo, por seu filho Fernando IV (1285-1312) e por seu neto, o próprio Afonso XI. No tempo destes reis, que foi muito extenso, nunca houve estabilidade de moeda: esta foi muitas vezes alterada e deteriorada. Não me parece que Pedro I (1334-1369) de Castela, filho de Afonso XI, tenha desvalorizado a moeda, o que é impressionante. Antes suspeito que, constrangido pelos muitos agravos vindos da alteração monetária de quando reinava seu pai, tenha se abstido de repeti-la e se preocupado em cunhar boa moeda - como o atesta o dinheiro que encontramos marcado com seu nome.

Seu irmão, Henrique II (1333-1379), premido pelas quantias que cedeu aos companheiros e ajudantes com os quais reivindicou seu reino, e onerado com (ilícitas e ainda maiores) dívidas futuras, recorreu a este remédio. Cunhou dois tipos de moeda: os reais, com valor de três maravedis, e os cruzados, com valor de um maravedi. Assim o atestam as crônicas, no ano 4, capítulo $10^{28}$. Graves perturbações logo surgiram deste procedimento, mas seus sucessores não temeram em imitar seu exemplo. Para pagar João de Gante (1340-1399), o Duque de Lencastre (de reino rival), o valor acordado para um pacto de paz, João I (1358-1390) concebeu uma nova moeda com o nome de blanca, com valor de

${ }^{27}$ C.R.C., Alfonso XI, cap. 10: "De lo que se fizo en este año en las Córtes de Carrion, et de otras cosas" [Todas as referências a esta extensa compilação se farão conforme: Crónicas de los Reyes de Castilla. Desde Alfonso el Sabio, hasta los Católicos Don Fernando y Doña Isabel. Colección ordenada por Don Cayetano Rosell. BAE. Madrid: Rivadeneyra, 1875-8. 3v.]

${ }^{28}$ C.R.C., Henrique II, ano 4, cap. 3: "Como D. Henrique mandó labrar una moneda que decian Cruzados, é otra que decian Reales". 
um maravedi, mas logo em seguida sancionou que seu valor, quase reduzido à metade, seria de seis dineros ${ }^{29}$, chamados novenes. Isto se deu nas Cortes de Briviesca, em 1387.

$\mathrm{O}$ desmando de perverter a moeda piorando sua qualidade e subindo seu valor prosseguiu no reino de Henrique IV (14251474), que, entre todos, foi o período de maior perturbação. Embora os historiadores de seu tempo não o tenham mencionado, isto se depreende claramente dos variados valores da prata. Pois, quando era rei Afonso XI, oito onças de prata (ou um marco) valiam 125 maravedis. No governo de Henrique II, o real de prata valia três maravedis, e consequentemente o marco valia cerca de $200^{30}$. Sob João I, filho de Henrique II, subiu a 250: o real de prata valia quatro maravedis, e o de ouro, cinquenta maravedis, ou doze reais de prata. As Cortes de Burgos o atestam (Lei $1^{a}$, ano de 1388) ${ }^{31}$. Sucedeu-o Henrique III (1379-1406), em cuja época este valor chegou a 480 maravedis, ou ainda a 500. No fim deste reinado e início

\footnotetext{
${ }^{29} \mathrm{O}$ autor se refere ao latim denariolis, mais propriamente "dinerillos". No presente contexto, o termo não exige tradução diferenciada. A própria versão castelhana traz dineros, e os trataremos como sinônimos, exceto se necessária alguma distinção entre os termos.
}

30 A edição latina apresenta dois erros tipográficos paralelos, decerto ocorridos quando da leitura do manuscrito. Ela discrepa da versão castelhana pela presença, na primeira, do termo bis ("duas vezes") antes dos numerais 125 e 200. Se preferíssemos o original, duplicar-se-iam ambos os valores. Isto, porém, obscureceria o argumento de Mariana, que consiste em expor uma ascensão contínua: $125,200,250,480$. Se a sequência (pouco coerente) fosse 250, 400, 250, 480, o autor não teria dito que o valor do marco "subiu a 250". Considerando também que, posteriormente (cap. 8), Mariana dirá de modo claro que as oito onças de prata valeriam 125 maravedis, deduzimos o erro tipográfico e lemos não bis, mas bes, ou seja, um marco (oito onças).

31 Mais conhecidas como Cortes de Palencia, estas assembleias tiveram alguns de seus primeiros documentos expedidos desde Burgos, por onde passava o rei a caminho daquela cidade (ver C.R.C., João I, ano 10, cap. 3-4). Sobre a referida lei, ver: Cortes, vol. II, p. 420-21 [Cortes de los Antiguos Reinos de León y de Castilla. Madrid: Rivadeneyra, 1863-1903, 5v]. As Cortes de Palencia foram mais propriamente uma continuação das extensas Cortes de Briviesca, de 1387. do de João II (1405-1454), este valor passou a 1000 maravedis. Finalmente, no de Henrique IV, avaliavam-no a 2000 e 2500. Toda esta variação e acréscimo não se deu por alteração do metal [do marco], que sempre continha oito onças de prata com pequena mescla de cobre, mas porque os maravedis (ou outras moedas) frequentemente tinham reduzida a sua qualidade, de modo que as moedas de prata pareciam subir de valor, se comparadas às demais. Estas variações da prata foram quase todas tomadas das Repetitiones de Antonio de Nebrija (1441-1522).

De fato, as moedas que existem destes períodos estão todas enegrecidas, como indício do desregramento com que naqueles tempos se viciava a moeda. Mas toda esta inconstância foi resistida - até agora - pela lei dos Reis Católicos Fernando II de Aragão ${ }^{32}$ e Isabel I (14511504) de Castela, que estabeleceram o preço das oito onças de prata bruta em 2210 maravedis, e seu valor como moeda a 2278, os quais se mantêm até hoje. Filipe II reduziu algo da qualidade e peso do maravedi, mas isto em nada alterou seu valor em relação à prata, por haver sido uma mudança insignificante.

Creio, por outro lado, que a alteração que agora se faz no dinheiro de cobre mudará seu valor - e o fará de tal maneira que oito onças de prata cheguem a valer 4000 destes maravedis que atualmente se cunham. Estará errada minha previsão?

\section{Capítulo VII As Conveniências Advindas da Alteração da Moeda de Cobre}

É necessário examinar em pormenor as conveniências e inconveniências que provêm da alteração da moeda de cobre. Que as

\footnotetext{
32 Pouco antes, Juan Mariana mencionou Fernando IV como um dos antecessores deste governante. A razão disto é que, embora comumente conhecido como Fernando II de Aragão, o Rei Católico era, como monarca de Castela, denominado Fernando V.
} 
ponhamos, pois, ante nossos olhos, para o leitor prudente e sábio considerar, com calma e sem preconceitos, qual delas é de maior monta; que venha assim a vitória em prol da verdade (E que outra intenção se deveria ter?).

Primeiro, se é feita esta alteração na moeda, poupamo-nos o custo da prata, cujo alto peso se mesclou ao cobre durante anos, sem qualquer proveito. A isto se presta a redução de qualidade. $\mathrm{E}$, com peso mais baixo, consegue-se transportá-la de modo mais ágil para onde o queiram os mercadores (o que antes era mais caro) e empregá-la mais facilmente no comércio. Segundo, haverá na nação grande abundância desta moeda; disto resultará maior capacidade para o comércio, ao passo que se restringirá a cupidez dos estrangeiros, que de outro modo lançariam suas ávidas e tenazes mãos sobre a moeda de ouro e prata. Os que a tiverem, de bom grado a passarão a outros: dívidas se pagarão, terras se cultivarão (com maior expectativa de abundância), oficinas se estabelecerão (frequentemente paradas por escassez de moeda). Assim, haverá maior fartura de gado, frutos e mercadorias, vestes de linho, lã e seda, e de todas as demais coisas que se vendem. Com a abundância certamente haverá preços baixos, ao passo que antes poucos eram os que conseguiam empréstimos de dinheiro, e ainda assim a altos juros.

Contentes com nossa sorte e abundância, necessitaremos de menos mercadorias do exterior, que com sua importação levam embora nossa prata e ouro e corrompem nossa gente com costumes estrangeiros - pois certamente com o conforto destes produtos debilitam-se fisicamente homens nascidos para a guerra e as armas, extingue-se dos ânimos o vigor marcial. Tampouco virão a nós com a mesma frequência os estrangeiros, tanto pela abundância que teremos de mercadorias nativas, quanto pela natureza de nossa moeda, pois, uma vez trocada por suas mercadorias, não quererão levá-la de volta à sua pátria (o que não lhes valeria de nada): com o dinheiro que receberam, comprarão mercadorias de nossa terra - o que será conveniente - e as levarão à sua.
É de grande relevância o fato de que, com este recurso, o rei trará ao erário muito dinheiro, com o qual se quitarão as dívidas junto àqueles com quem estão penhorados os tributos régios - uma grande calamidade! - e isto sem qualquer injustiça e protesto, apenas com a alteração da moeda. Sem dúvida, o rei obterá grande lucro. Confirma Plínio, o velho (no ponto antes citado) que os romanos emergiram de grandes dificuldades diminuindo o peso do asse; assim pagaram as dívidas que os oprimiam. Resultado semelhante se narra nas Crônicas de Afonso XI, rei de Castela, no capítulo $98^{33}$. O mesmo vale para Henrique II, ano 5 , cap. $10,{ }^{34}$ que por este recurso se livrou da gravíssima dívida de guerra que o oprimia, contraída junto a Beltrán de Claquín (13201380) e outros estrangeiros, com cujo auxílio tomara o reino de seu irmão.

A isto agrego que a moeda de cobre puro - sem mescla de prata, nem de qualquer outro metal precioso - tanto foi usada pelos antigos romanos quanto o é por outros povos de nossa época. E parece ter sido mais comum e mais usada que outras, visto que os romanos vulgarmente chamavam de "cobre" o seu dinheiro. Talvez por isso tenha chegado a nós o hábito de descrever em maravedis quanto de bens tem uma pessoa, ou qual a sua renda anual. E consta que em certa época nós espanhóis usávamos maravedis de ouro. Portanto, se o tempo (cujas forças são grandes) arrebatou desta moeda todo o ouro, não seria de admirar se agora a prata é retirada da liga de nosso dinheiro, onde não tinha nenhuma serventia, nem nunca trazia benefício a quem quer que fosse.

Todas estas conveniências são de grande vulto, e para que tenham lugar talvez seja justo desconsiderar as inconveniências que qualquer leitor atento venha a indicar sobre esta recente proposta. Pois nada nesta vida é perfeito e livre de todos os males e repreen-

\footnotetext{
${ }^{33}$ C.R.C., Alfonso XI, cap. 95: “De como el Rey partió de Segovia, et fué á Valledolit, et mandó facer el ordenamiento en que se labrase la moneda, et de otras cosas".

${ }^{34}$ C.R.C., Henrique II, ano 4, cap. 3.
} 
sões. O dever do homem prudente é buscar aquelas coisas que tragam os maiores e menos censuráveis benefícios, especialmente porque a natureza humana é corrupta nesta sua condição ${ }^{35} \mathrm{e}$ sempre costuma denunciar novas ideias e artifícios, apegada a costumes de antanho, como se nada pudesse ser corrigido ou agregado às instituições dos antigos.

\section{Capítulo VIII \\ Os VÁrios Tipos e Valores dos Maravedis em Castela}

Antes de estender-me sobre os inconvenientes que me parecem necessariamente conectados ao novo intento de desvalorizar a moeda de cobre, parece-me importante explicar os vários gêneros de maravedis usados em Castela ao longo dos séculos, assim como seus valores. Trata-se de questão convoluta e complexa, mas necessária, se mediante nosso esforço há de ver a luz uma verdade até agora enterrada em densa treva - empresa da qual não desesperamos.

Em primeiro lugar vieram os maravedis de ouro, em frequente uso no tempo dos godos. Como foi dito, os imperadores romanos mais tardios cunharam moedas de ouro menores que as antigas: de uma onça faziam seis, de um marco faziam 48, pouco maiores que os nossos castellanos. Chamaram de soldos ${ }^{36}$ estas moedas de ouro, e valia 12 denários cada uma. Se o denário romano se estima em 40 quadrantes (ou maravedis), o valor do soldo será de 480 maravedis, que é o mesmo do nosso castellano. Por isto, os soldos de época posterior, embora feitos de prata e depois de cobre em sua maior parte, sempre retiveram o valor proporcional de doze denários - já estes também feitos não de prata, mas de cobre. Também na França e em Aragão, onde o nome "soldo" permanece, cada um vale doze dineros ${ }^{37}$.

${ }^{35}$ QUINTO CÚRCIO. História de Alexandre Magno. VII, 4.

${ }^{36}$ No original em latim: solidus.

${ }^{37} \mathrm{Ou}$ seja, denários.
Vigorava na Espanha o Império Romano - e com ele naturalmente a moeda, as leis e os costumes romanos - quando a invadiram à espada os godos. Apesar da mudança de poder, não apenas os vencedores transmitiram seus costumes aos vencidos, mas também os vencidos aos vencedores. Inicialmente, os godos usaram a moeda romana. Em seguida, estabelecido o novo império, conceberam e cunharam nova moeda, à qual chamaram maravedi. ${ }^{38}$ Não é necessário que nos detenhamos no exame desta palavra, mas no fato de que cada um daqueles maravedis valia dez dineros e 400 quadrantes, o mesmo valor de nossa moeda de ouro castelhana atual: 400 quadrantes (isto é, 400 maravedis atuais). Por isto manteve-se desde o início que o maravedi, embora feito de prata e em seguida de cobre, sempre vale dez dineros $(\mathrm{Na}$ nossa lei, o maravedi vale duas blancas, seis coronados, dez dineros e sessenta meajas. Por seu valor ínfimo, estas moedas quase desapareceram; quando vigoravam, porém, assim se relacionavam com o maravedi). Entre o soldo romano e o maravedi de ouro dos godos, a discrepância era mínima. Assim, no lugar dos soldos que a lei romana prescrevia para as multas, era de costume no Forum Iudicum

\footnotetext{
${ }^{38}$ Apesar do que neste parágrafo afirma o autor - que na versão castelhana dá como fonte não só o Forum Iudicum (Fuero Juzgo), mas o Codex Euricianus (Leyes Góticas), dois corpos legais visigóticos - o termo "maravedi" só constaria de traduções bem posteriores aos originais latinos dos documentos. Nestes, lê-se solidus (soldo), moeda realmente presente naquele império. Embora o autor nos vá fazer notar - corretamente - que o soldo visigótico (herdeiro ibero do sistema romano) tenha sido na prática igualado ao maravedi, esta moeda em particular não foi propriamente visigoda, mas posterior. Tanto ela quanto o termo que a representa ainda não haviam surgido antes do século XI, quando da invasão dos almorávidas (al-murabitûn), dinastia que, no poder, deu então seu nome (murabití, "maravedi") ao dinar mouro. Este detalhe, embora digno de nota, não invalida a exposição de Mariana, pois aqui apenas comparam-se proporções monetárias e mostra-se certa persistência do sistema romano. O maravedi se introduziu, como o fizeram outras moedas do califado ao longo daqueles anos, tendo como substrato a apropriação visigótica da moeda romana.
} 
(do qual provinha o direito naquele império) indicar o mesmo número de maravedis de ouro. Hoje na Espanha desenterram-se muitas moedas góticas de ouro impuro, que, derretidas, mostram ter dele apenas a metade (são os chamados semisses do maravedi gótico) ou mesmo um terço (os tremisses, de cujo valor trataremos posteriormente).

Vieram tempos muito turbulentos, e a moeda também foi afetada pela confusão. Numa Espanha domada pelas armas dos mouros, surgiu nova progênie de reis, para a salvação de uma gente oprimida por males com que o Céu a puniu. Não trataremos da moeda dos mouros. No governo dos reis de Leão e Castela, surgiram três maravedis. Os de ouro (também chamados bons), os velhos e os correntes (ou seja, usuais).

Tratemos primeiramente dos usuais e descrevamos seu valor e qualidade, pois o entendimento dos outros dois depende da explicação destes. $\mathrm{O}$ valor dos usuais não foi único, mas variado, e alternou-se com o tempo. Esta variação é certamente difícil de definir. Não há como tecer uma conjectura senão a partir do próprio valor do marco de prata. Para compararmos aqueles maravedis aos nossos, é necessário fazê-lo segundo a mesma proporção em que o valor do marco de cada época se compara ao da nossa. Pois bem: atualmente, um marco de prata bruta vale 2210 maravedis; como moeda, vale 2278. Não convém deter-se na qualidade da prata, pois em todas estas épocas ela teve aproximadamente a mesma qualidade de hoje, o que podemos aferir pelos cálices e demais instrumentos litúrgicos há muito preservados nas igrejas. Adiciono que o marco de prata, embora tivesse valor variado se comparado aos maravedis, sempre valeu cinco moedas de ouro - comumente chamadas doblas ${ }^{39}$ - as quais valiam 12 moedas de prata cada (não 14, como dizem alguns). O marco valia, pois, 60 ou 65 moedas de prata. Isto depreendemos das leis de João I, rei de Castela.

Mas a discussão ruma a esta outra fonte. $\mathrm{O}$ mais antigo valor do marco que

\footnotetext{
${ }^{39}$ Ou seja, "dobrões".
}

podemos aferir é de 125 maravedis. Este foi o valor do marco durante o reino de Afonso XI, conforme o atestam as Crônicas, cap. $98^{40}$. Portanto, valia dois maravedis a moeda de prata que hoje vale 34. Assim, o maravedi daquela época valia 17 dos nossos e um pouco mais; e era seguramente de prata, como o próprio valor nos indica. No reino de Henrique II, a moeda de prata valeu três maravedis, como nos contam suas Crónicas, ano 4, cap. $2^{41}$. Assim, o valor do marco subiu a 200 dos maravedis então em uso, e consequentemente cada um destes valeria 11 dos nossos atuais. A Henrique II sucedeu João I, em cujo reino o marco de prata subiu a 250 maravedis (ou quadrantes), visto que a moeda de prata valia quatro maravedis, e a de ouro, 50. Isto consta da Lei $1^{\text {a }}$ das Cortes de Burgos, do ano de 1388. Deste modo, naquela época o maravedi valia nove ou dez dos nossos atuais. Para mostrá-lo mais claramente, basta que consideremos esta outra lei de Briviesca, que pune ofensas a pais e mães com multa de 600 maravedis $^{42}$. No tempo dos reis Fernando e Isabel, esta lei foi incluída no Ordinamentum (VIII, tít. 9, lei $1^{a}$ ), onde se observava que os 600 maravedis nela mencionados eram bons e valiam 6000 maravedis do seu tempo - e também do nosso (pois, desde a época dos Reis Católicos, não houve nenhuma alteração no marco de prata, nem no maravedi).

Passemos a outros monarcas. Conforme vejo em documentos antigos, no reino de Henrique III o marco chegou a valer 480 ou ainda 500 maravedis. Nesta época, portanto, a moeda de prata valeu por volta de oito mara-

${ }^{40}$ C.R.C., Alfonso XI, cap. 95. Não apenas da edição de 1857 que utilizamos, mas também noutra anterior (Madrid: Antonio de Sancha, 1787. cap. 98), consta que o valor do marco seria mais exatamente de 100 maravedis, e que apenas após algum tempo foi elevado (por uma carestia) a 120. Embora esta discrepância pudesse afetar os valores descritos, ela não iria de encontro ao argumento de Mariana, mas em seu favor, visto que a desvalorização do maravedi teria sido ainda mais acentuada entre Afonso XI e Henrique II.

${ }^{41}$ C.R.C., Henrique II, ano 4, cap. 3.

${ }^{42}$ Cortes. vol. II, p. 365-66. 
vedis - e consequentemente cada um deles valia quatro ou cinco dos nossos. No reinado de João II (filho de Henrique III) o marco passou a valer 1000 maravedis, especialmente no fim de sua vida. Logo, os de seu tempo já valiam dois e meio dos nossos - uma assombrosa variação, mas que não cessou naquele reino. Pois no governo de Henrique IV, em que se deram graves e numerosas perturbações, o marco de prata subiu a 2000 maravedis e depois a 2500, como nos conta Antonio de Nebrija em suas Repetitiones. Seu maravedi valia tanto quanto o nosso, e desde então não houve nenhuma grande alteração em seu valor - o que se deve atribuir à diligência de Fernando e Isabel, assim como de seus sucessores. Agora, munidos das leis e crônicas de nossos monarcas anteriores, tratemos dos demais maravedis.

O maravedi de ouro era igual a seis daqueles que se usavam comumente no tempo de Afonso X, o Sábio. Como o afirmam as Leyes del Estilo (n $\left.{ }^{\circ} 114\right)$, sob aquele monarca verificou-se que seis maravedis de sua época tinham o mesmo peso de um dos de ouro. Isso não significa que os maraved is de Afonso $X$ fossem de ouro, como o suspeitam alguns; chegou-se a tal valor considerando-se o peso os maravedis dos dois tipos e a proporção do ouro para a prata, que é de doze para um. A lei de Afonso XI, por sua vez, promulgada nas Cortes de Leão de $1349^{43}$, afirmava que 100 maravedis de boa moeda (ou, neste

43 Tanto no original quanto na versão castelhana, lê-se que tal parlamento ocorreu "na era de 1387", ou seja, em 1349 (quando de fato reinava Afonso XI, e tiveram lugar aquelas cortes). Sempre que apresentado de tal maneira, o ano refere-se à chamada era hispânica, proclamada em 38 a.C. sob Otávio Augusto (63 a.C.-14 A.D.), quando da pacificação da península ibérica e sua inserção na civilização romana. $\mathrm{O}$ uso contínuo desta datação em paralelo com a contagem cristã daquela região durante quase toda a Idade Média (a contagem das Crônicas e Cortes é sempre dupla, por exemplo) dá testemunho de como as invasões visigóticas não eliminaram o sentido de identidade dos hispanos conquistados. Ao contrário, o império visigodo se viu, sob este e vários outros aspectos, como herdeiro e continuador do mundo romano cristianizado. caso, de ouro) valiam 600 dos comuns. Desta passagem podemos tirar duas conclusões, a saber: primeiro, que do tempo de Afonso X, o Sábio, até o de seu bisneto, Afonso XI, em nada se alterou o valor do marco e do maravedi, visto que sob ambos o maravedi de ouro equivalia a seis dos usuais. Segundo, que, se o maravedi usual valia 17 dos nossos atuais (ou até um pouco mais, como dito antes), então necessariamente equivocam-se os que avaliam o maravedi de ouro em 36 ou 60 dos nossos: ele valeria três moedas de prata, ou seja, mais de 100 dos nossos maravedis $^{44}$. Trata-se de opinião nova, mas assentada sobre bons fundamentos.

Suspeito, ademais, que estes maravedis de ouro não seriam outra coisa que os tremisses dos godos, dos quais se valeram estes primeiros reis de Castela, que não cunharam novos. Primeiro, por verificar-se que seu valor é, também, de três a quatro moedas de prata; segundo, porque os desenterramos com muita frequência, mas não encontramos nenhum com a efígie ou o nome dos reis de Castela. Quem creria que desapareceram todos, sem qualquer vestígio? ${ }^{45}$

Já tratamos do maravedi de ouro. Quanto ao maravedi velho, diz-se que ele vale

${ }^{44}$ Mais precisamente, $6 \times 17=102$. Quanto à proporção com as três moedas de prata, lembremos que dois maravedis comuns equivaliam a uma moeda de prata no reino de Afonso XI, da mesma maneira que 34 maravedis comuns o faziam no tempo de Mariana. Como disse o autor, a prata pura não mudou seu valor intrínseco. No original, a sentença latina - argentei trescentum amplius Maravedinos - parece dizer "mais de trezentos maravedis de prata" (lendo trescentum como trecenti), o que não é correto, e confirma-o a versão castelhana, onde lê-se "tres reales de plata y aun algo más". Prefira-se ler, portanto: "argentei tres [seu] centum amplius Maravedinos".

${ }^{45}$ Pareceria difícil conciliar esta possibilidade com a afirmação anterior de que o maravedi de ouro original ("gótico", como o propunha o autor) equivalia ao soldo romano, e que ademais valia três dos maravedistremisses góticos (como ele próprio afirmou). A não ser que se entenda que o maravedi bom (ou de ouro) aferido por Afonso X já fosse a versão um tanto desvalorizada (o tremisse) daquele maravedi "gótico" original, mencionado no início do capítulo. 
um e meio dos nossos. Disto melhor falarão aqueles que conhecem mais profundamente a lei do reino; talvez tenha sido o consenso dos jurisconsultos que, nas multas, se substitua um maravedi velho por um e meio dos nossos, sempre que o termo aparece no texto de nossas leis - do mesmo modo que o maravedi de ouro encontrado nestas leis é comumente avaliado a 36 ou 60. Mas, se falamos precisamente, o "maravedi velho" não teve um valor só, mas variado e múltiplo; toda vez que algo se subtraía da qualidade da moeda (o que se faz com frequência), os reis concediam - para não ter que abolir os maravedis anteriores - que estes fossem correntes junto com os novos, e que se chamassem velhos.

Assim, será fácil comparar entre si (e com os nossos) os maravedis usuais de uma geração ou outra. O maravedi de Afonso XI, comparado ao o que se cunhou sob seu filho Henrique II, pode dizer-se velho, e valerá um e meio [dos usuais de então]. Se comparado com o nosso, valerá não menos que 17. Os maravedis velhos, pois, foram os usuais em algum momento. Logo, a partir do valor dos usuais cabe-nos estabelecer (conforme explicamos) quanto valem os antigos; e, destes que se dizem novos, quanto valem comparados aos nossos. Estas são miudezas espinhosas, mas já estamos chegando ao seu final.

Em nossas leis, denomina-se "maravedi novo" não só este que corre em nossa época, mas também o que corria no tempo do rei Fernando, o Católico. Naquele tempo, recompilaram-se em alguns poucos volumes as leis dos reis que o precederam; chamaram-se então "maravedis velhos" os destes monarcas anteriores. Podemos, portanto, a partir do valor do maravedi que foi usado por cada um deles, reconstruir o valor deste maravedi velho. $\mathrm{O}$ de Afonso XI valia 17 dos nossos. $\mathrm{O}$ de Henrique II valia 11. O de João I valia dez. $\mathrm{O}$ de Henrique III, cinco. O de João II, dois e meio. Devem-se considerar as épocas atentamente, e ante elas estabelecer quanto valia o maravedi velho em cada lei, e quanto valeria o novo - seja entre eles próprios, seja deles com relação aos nossos.
Tampouco devemos esquecer que o maravedi velho às vezes se diz bom, como vimos na lei antes mencionada (Ordinamentum VIII, tít. 9, lei $\left.1^{\mathrm{a}}\right)$, na qual observaram que eram bons (e valiam 6000 dos seus usuais) os 600 maravedis com que João I ordenara se multassem os que ofendiam pai e mãe. Decerto a lei não se refere a maravedis de ouro, que valiam muito mais, mas aos velhos, que, sendo os usuais daquele reino (o de João I), valem dez vezes os nossos. (Recordemos que o valor do maravedi não se alterou desde Fernando, o Católico.)

Por outro lado, consideremos esta lei, promulgada em 1409, em Guadalajara, por João II (Ordinamentum VIII, tít. 5, lei 2a): nela, quem esteja excomungado por um mês deve pagar 100 maravedis bons, que valem 600 dos velhos; se a contumácia chegar a seis meses, que pague 1000 maravedis bons, que valem 6000 dos velhos. Neste caso, os maravedis bons são os de ouro; os velhos eram os correntes no tempo de Afonso X a Afonso XI. Pois, como antes dissemos, apenas naquele tempo os maravedis de ouro valiam seis dos usuais. A propósito: se a alguém lhe parece dura aquela multa, que chega a 3000 das nossas moedas de ouro, é certamente mais severa a atual, que pune como suspeito de heresia quem permanecer excomungado por um ano.

Por último, cito as Crônicas deste mesmo rei João II (ano 29, cap. 145), ${ }^{46}$ quando nas Cortes de Burgos o monarca expediu ordem para cunhar maravedis-semisses (que, por sua alvura, chamamos blancas) da mesma qualidade e peso com que os havia feito seu pai, Henrique III. Muito posteriormente, foi visto que a referida

${ }^{46}$ C.R.C., João II, ano 23, cap. 35. Como o atestam os livros destes parlamentos (ver Cortes, vol. III, p. 7980 ), as referidas Cortes de Burgos, embora comumente datadas de 1430, iniciaram-se no fim de 1429. Que o ano de 1429 seja o $23^{\circ}$ ano do reinado explica parte do erro no texto original. Em 1430, esta assembleia se traslada a Medina del Campo. Sobre seu contexto e relevância, ver: COLMEIRO, Manuel. Cortes de los Antiguos Reinos de León y de Castilla; Introducción. Madrid: Rivadeneyra, 1883-1884. vol. I, p. 444-49. 
moeda era inferior, e os procuradores do reino puseram todo o tema a exame. Reconhecidos o vício e o engano na cunhagem, determinou-se que o maravedi velho (de Henrique III) valeria um e meio dos novos. Isto consta do ano 42 de João II, cap. $36^{47}$.

Observemos que nesta passagem parecem ter encontrado razões para emitir juízo aqueles que declararam universalmente que um maravedi velho vale um e meio dos nossos, quando deveriam antes dizer que o maravedi cunhado por Henrique III valia um e meio dos que João II cunhou. Ainda assim, se considerarmos o valor do marco sob estes dois reis, o desvio não estaria satisfatoriamente sanado, pois um maravedi anterior valia dois inteiros dos posteriores: com efeito, comparado aos nossos, o maravedi de João II valia dois e meio, enquanto o de Henrique valia quatro ou cinco - o que é evidente e manifesto, por tudo que expusemos nesta discussão. cos

${ }^{47}$ C.R.C., João II, ano 36, cap. 6. (O erro é de mesma natureza do anterior: 1442 é o $36^{\circ}$ ano do reinado). Apesar do termo "maravedi" aqui empregado, o referido ajuste proporcional (de 1,5 para 1) se aplicou primeira e materialmente entre as blancas dos dois reinados. Assim rezava o texto: "E conoscida la ventaja que habia de las viejas á las nuevas, mandó que de las blancas nuevas valiesen tres un maravedi, é quelas viejas quedasen en su valor, valiendo dos un maravedí". Concebido tal ajuste entre os maravedis propriamente ditos, o resultado seria que de fato os velhos valeriam um e meio dos novos. Não obstante, já vimos que para o autor - que o confirma em seguida - os velhos valeriam o dobro destes em uso no reinado de João II, e portanto a proporção de 1,5 para 1 entre maravedis ainda teria deixado a desejar. 